\title{
HERSTEL VAN DIE EVANGELISTE-AMP deur
}

DR. D. J. BOOYSEN

\section{HOEKOM ?}

Geen persoon wat op hoogte is met die godsdienstige lewe van die blanke Suid-Afrikaners sal dit betwyfel dat die probleem van buitekerklikheid in omvang besig is om fenomenale afmetings aan te neem. Daar is al etlike kere aangetoon met behulp van statistieke hoe groot die probleem dan ook is. Cronje e.a. ') het die bewering gemaak dat die kenmerkende eienskap van die kerkbesoek in die drie Afrikaanse Kerke is of word die ongereelde kerkbesoek. De Wet het tot die slotsom gekom dat die gemiddelde kerkbesoek slegs $19 \%$ vir twee eredienste per Sondag beloop. ") As die stelling van Prins ${ }^{3}$ ) hier in aanmerking geneem word dat die mense geneig is om van 'n bloot nalatige kerkbesoek voort te gaan op die pad wat lei tot algehele kerkloosheid dan kan verwag word dat die probleem steeds sal vererger.

Dit is onrusbarend as 'n kerklike kommissie ${ }^{4}$ ) moet rapporteer dat daar letterlik duisende lidmate is waarmee die kerk kontak verloor het en dat dit voortgaan teen 'n tempo van duisend lidmate per jaar. Uit die voorgaande is dit duidelik dat hierdie gegewens betrekking het op diegene wat wel op een of ander stadium kerklik verbonde was maar in die huidige situasie vervreemd geraak het van die kerk. Duidelikheidshalwe kan gekonstateer word dat verskillende groeperinge t.o.v. die buitekerklikes gemaak kan word, maar dat in die loop van die betoog slegs met die genoemde groep rekening gehou word.

As hier nou in ag geneem word dat die kerk met 'n steeds groeiende probleem te make het moet gevra word na die moontlike bekamping daarvan.

1) Dr. G. Cronje e.a., Kerk en Huisgøsin. N.G. Kerk Uitgewers, Pretoria 1958 , bl. 108.

2) Dr. J. I. de Wet. Die Kerklike Verkondiging in die Huidige Tydsgewrig, ongepubliseerde D.D.-preekskrif, Universiteit van Pretoria, 1961, bl. 2.

3) Dr. S. J. Prins, Kerksheid. Persoonlikheidstrekke en Agtergrond by die Vroegvolwassene, Ongepubliseerde D Litt. et. Phil.-proefskrif, Universiteit van Suid-Afrika, 1965, bl. 4.

4) J. D. H. Smit e.a., Rondom die Apostolaat van die Kerk, (Hervormde Teologiese Studies, 20e Jaargang, Af. 1. Aug. 1964), bl. II VV. 


\section{Die Huidige Ampte in die Kerk :}

Die kerk onderskei drie ampte, nl. :

a. die dienaars van die Woord.

b. die ouderlinge.

c. die diakens.

Hier volg die kerk die voetspoor van die Nederlandse Geloofsbelydenis (Art. XXX) en dit is dieselfde as diè wat Calvyn ${ }^{5}$ ) aan die kerk voorhou. Hierdie ampte het almal een en dieselfde funksie nl. die Verkondiging, maar dit neem verskillende gestaltes aan in die verskillende Ampte. Wat van die verskillende Ampte verwag word, word uiteengesit in die onderskeie bevestigtingsformuliere en word deur die kerke bepaal en nader omskrywe in die toepaslike Kerkwet of -orde. By die nagaan van die Kerkwet of -orde is dit opvallende dat hierdie Ampte 'n sterk behoudende karakter dra, waaruit miskien gekonkludeer kan word dat die kerk in die Ampsbegrip 'n bewarende element opgesluit sien lê. Dit het vraagstuk geword of daar in die kerk voorrang verleen moet word aan die bewaring of aan die vermeerdering. ${ }^{6}$ )

Die belangrikheid van albei mag nie ontken word nie en feit is dat ook nie een nagelaat mag word nie. Die feitlike situasie is egter dat die kerk in die Ampte alle klem lê op die bewaring van die gemeente - en uit die statistieke vermeld blyk dit dat hierin ook nie geslaag word nie. Aan die uitbreiding van die kerk onder die buitekerklikes word in werklikheid nie veel gedoen nie. Trouens dit is slegs benadruk in die uiteensetting van die diakenswerk. Daar word pertinent genoem dat aandag - in die sin van barmhartigheid wat bewys moet word - bestee moet word aan diegene wat vreemd is vir die gemeente. Hierdie oorbeklemtoning van die bewarende funksie in die bestaande ampte kom duidelik na vore in die opleiding van die Bantoeleraars. Die kerk is besig om sy opvatting van die ampte oor te dra aan die Bantoe. Dit is daarom nie vreemd dat daar heel onlangs probleme ontstaan het met 'n Bantoeleraar wat as vereiste gestel het om in 'n georganiseerde gemeente geplaas te word en nie bereid is om inderwaarheid sendingwerk te doen en 'n gemeente op te bou nie.

Vanweë die nood van die kerk wat gekonfronteer word met

5) J. Calvyn. Institusie IV, 3, 4-8.

6) Vgl. dr. J. Overduin, Tact en Contact, J. H. Kok, N.V. Kampen 1958 , bl. 24 V.V. 
'n groot aantal afvalliges en vervreemdes sal die kerk genoodsaak wees om uitweg te soek ten einde konstruktief vermeerderend werksaam te wees.

\section{Wysiging in die getal van ampte :}

Dit is te verstane dat geen kerk maklik sover sal kom hier wysiging aan te bring nie. Die Afrikaanse kerk is sterk Calvinisties georienteerd en Calvyn was die mening toegedaan dat ampte soos diè van die Apostels, profete en evangeliste vanweë die noodsaak en behoefte van die bepaalde tyd ingestel is. Hulle is tydelik van aard en moet uiteindelik tot niet gaan en hy wil in die behoorlike ingerigte kerke geen plek aan hulle toeken nie. ') Tog verkies ek hierdie opvatting van Achelis. ${ }^{8}$ ) „Het aantal en de inhoud der ambten naast de bediening des Woords, moet bij zekere vastheid, naar tijd en gelegenheid kunnen gewijzigd worden". Dit is in die gesindheid dat Engelbrecht dan verklaar : "In aktuele praktiese beslissings laat die kerk homself lei deur die Woord van God, die Belydenis van die Kerk, die gebruike van die Kerk (waarvan sommige in die Kerkorde aangeteken is) en deur die konkrete situasie waarin die Kerk hom op 'n bepaalde oomblik bevind". ${ }^{9}$ )

Die uitsprake van Achelis en Engelbrecht behels dus die moontlikheid van variasie op grond van behoorlike besinning en bestudering van die Woord van God ens., en dit beteken dat die huidige getal van ampte nie vasgevang is in 'n onveranderbare geheel nie. Wie erns maak met die huidge situasie waarin die kerk verkeer sal die tekort in die bestaande ampte insien en besef dat wysiging noodsaaklik is.

\section{Die Evangeliste :}

Wanneer nou gevra word na 'n amp om die bestaande ampte in die kerk aan te vul kan ons voorkeur verleen aan die Evangeliste. In die Skrif is nie 'n oormaat gegewens oor hulle verstrek nie.

Die evangelis word slegs drie keer pertinent genoem :

a) Hand. 21:8b. , . . . en ons het ons intrek geneem in die

i) J. Calvyn. Institusie. IV. 3, 3-8.

*) E. Chr. Achelis. Praktische Theologie bewerk deur L. W. Bakhuizen van den Brink. Kemink en Zoon. Utrecht 1906, bl. 61.

פ) Prof. dr. B. J. Engelbrecht. De Toelating van div Vrou tot dic Kerkliks Amnte. 'n Verslag aan die H.E. Algemene Kerkvergadering van 1964 (Ned. Herv. Kerk van Afrika) J. J. bl. 1, opgeneem in die Agenda en Bylae tot die Agenda. 
huis van Filippus, die Evangelis, wat een van die sewe diakens was, en by hom gebly".

b) Efes. 4:11. „En Hy het gegee sommige as apostels, ander as profete, ander as evangeliste, ander as leraars".

c) II Tim. 4:5b. „... doen die werk van 'n evangelis ..."

Dit is goed moontlik om 'n paar afleidings uit die geringe gegewens te maak. Filippus word hier evangelis genoem om hom te onderskei van die apostel. ${ }^{10}$ ) Die werkwoord euangelidziomai word i.v.m. Filippus ook nog gebruik in Hand. 8:12, 25, 40. $\mathrm{Hy}$ is een van die sewe diakens, en een van die leiers van die Helleniste in die Jerusalemse gemeente. Heel waarskynlik het die diakens na die marteldood van Stefanus (Hand. 6:8 v.v.) leiding geneem onder die Helleniste van die diaspora. ${ }^{11}$ ) Grosheide ${ }^{1 "}$ ) verklaar dat Filippus tot diaken gekies is omdat hy, of terwyl hy, evangelis is. Feit is dat hoe ons ookal die verband tussen die diakensamp en evangeliste-amp wil sien, die mense leiding geneem het in die werksaamhede van die gemeente. Te groot aksent moet nie op die bekleding van twee ampte gelê word nie omdat die afgrensing in die vroeg-christelike kerk maar vaag was. Vir ons is van belang om te weet dat die evangeliste ' $n$ belangrike rol gespeel het en leiding geneem het in die gemeente. Ons kan uit die gedeelte ook ' $n$ ander afleiding maak wat in 'n mate afwyk van die algemene opvatting van die evangelis se werkwyse. Filippus woon in Cesarea. Paulus en sy geselskap gaan by hom tuis. Kan hieruit afgelei word dat die algemene opvatting van die evangelis as 'n rondreisende sendeling nie altyd steek hou nie? Filippus is hier 'n gevestigde persoon. Dit is ook die indruk wat geskep word deur Hand. 8:40: „Maar Filippus is in Asdod gevind. En hy het die land deurgegaan en die evangelie verkondig in al die stede, totdat hy in Cesarea gekom het".

Hierteenoor staan die geval van Timotheus. Hy is een van Paulus se medewerkers op die tweede en derde sendingreis. Tog is die moontlikheid dat Timotheus hom vir 'n tydlank altans in Efese (na die derde sendingreis) gevestig het (1 Tim. 1:3) nie uitgesluit nie. Hoogwaarskynlik het Timotheus hom nog daar beving tydens Paulus se tweede gevangenisskap waarop Paulus hom

10) Vgl. bv. C. S. C. Williams, The Acts of the Apostles, Blacks New Testament Commentaries, Adam and Charles Black, London, 1957, bl. 273.

11) Vgl. F. F. Bruce, The Acts of the Apostles, the Tyndale Press, London. 1956 , bls. 387 .

12) Dr. J. W. Grosheide, De Handelingen der Apostelen, II, H. A. van Bottenburg, N.V. Amsterdam 1948, bl. 257. 
na Rome laat kom het (II Tim. 4:9, 21,13) As hieruit tot 'n slotsom geraak moet word kan hoogstens gestel word dat die evangeliste nie net rondgereis het nie, maar na alle waarskynlikheid hulle werksaamhede voortgesit het, op die plekke waar hulle hul gevestig het, miskien in samewerking met die ander ampsdraers.

Uit II Kor. 8:19 kan ook 'n bepaalde verhouding tussen die gemeentes en die evangelis afgelei word want hiervolgens word die evangelis deur die gemeentes gekies as reisgenoot vir Paulus. Die gemeente het blykbaar seggenskap gehad in die aangeleentheid en hy was heelwaarskynlik 'n vertroueling by hulle gewees. Ofskoon slegs in hierdie enkele gevalle direk na die evangelis verwys word, was hulle in getalle baie groter. By implikasie word ook meer male na hulle verwys. ${ }^{14}$ )

Die belangrikheid van die evangeliste is daarin geleë dat hulle die Evangelie verkondig het soos hulle daartoe deur ander mense onderrig is. Hulle is nie direkte ontvangers van die Openbaring soos die apostels nie, bygevolg moes hulle onderlê word in die Evangelie en word hulle verkondigers ,des apostolischen Evangeliums. ${ }^{15}$ ) Hulle opdrag is duidelik : Kerussein ton logon (2 Tim. 4:2). Hulle is medewerkers in die Evangelie van Christus (I Thes. 3:2) of soos dit ook gestel word: Hulle het in die Evangelie gedien (vgl. Filip. 2:22). Die onbekende Evangelis (2 Kor. $8: 18,19)$ is medeverantwoordelik vir die kollekte vir die Jerusalemse gemeente. Verder kan ook vermeld word dat die evangeliste na die voorbeeld van Epafras waarskynlik die taak gehad het om die gemeente te leer. ${ }^{16}$ ) Dit gaan hier nie slegs om die verneem van die genade van God in waarheid nie maar manthano beteken eintlik „om te leer deur onderrig" ${ }^{1 i}$ ) en het derhalwe dieselfde drakrag as didasko. ${ }^{19}$ )

$\mathrm{Na}$ aanleiding van die voorbeeld van Filippus weet ons ook dat die evangelis wel die sakrament van die doop bedien het (Hand. 8:12, 38). Wanneer die verkondiging tussen die Apostels

13) Vgl. ook Wilhelm Michaelis. Einleitung in das Neue Testament, Berchthold. Haller Verlag. Bern 1954, bl. 259.

14) Hand. 8:4. 12, 35, 40, Filip. 2:22, 43. 1 Thes. 3:2 asook 2 Kor. 8:18, Kol. 1:7, 4:12.

15) Heinrich Schlier, Der Brief on die Epheser, Patmos-Verlag, Düsseldorf 1958, bl. 196.

16) J. E. Uitman, De Brief van Paulus aan de Colossensen, G. F. Callenbach. N.V. Nijkerk 1964, bl. 10.

1i) Vgl. W. F. Arndt und F. W. Gingrich, A Greek-English Lexicon of the New Testament and Other Early Christian Literature, University Press. Cambridge, 1957, bl. 491.

18) Vgl. K. H. Rengstorf, THWNT IV, bl. 408. 
en die evangeliste vergelyk word kan dit gestel word dat die evangeliste se bevoegdheid eiesoortig is. Hulle is nie ondergeskik aan die apostels nie maar hulle werk het 'n aanvullende karakter. Hulle werk het egter altyd verband gehou met die van die apostels en dit kan aanvaar word dat die evangeliste deur die apostels in hulle werk opgelei is.

\section{Praktiese Voorstelle :}

Die herlewing van die evangeliste-amp kan die kerk alleenlik ten goede kom. Ons het hierbo aangetoon dat onderhewig aan bepaalde voorwaardes die getal ampte gewysig kan word. Die kerk sal egter met die nodige versigtigheid aandag aan die hele aspek en aan alle ampte moet gee.

Die feitelike situasie is naamlik so dat die een amp in omvang toegeneem het ten koste van die ander. Die verskraling van die ampte dien geen goeie doel nie.

Wanneer die Kerk die feitelike nood van buitekerklikheid in oënskou neem sal besef word dat nuwe weë en middele gevind moet word wat kan meewerk in die stryd van die kerk teen die buitekerklikheid. As daar dan naas die dienaar van die Woord in elke gemeente 'n aantal evangeliste werksaam kan wees moet dit meewerk tot bekamping van die onderhawige probleem. Die uitspraak van die Tambaram-byeenkoms : „We recognise at the same time that there is a special gift for evangelism which may lead to the setting apart of fulltime evangelists to carry on work in a more specialised way than the pastor". ${ }^{19}$ ) is in die huidige situasie daarom van belang.

In der waarheid is die evangelis dan ook nie 'n vreemde verskynsel vir die Nederduitsch Hervormde Kerk van Afrika nie. 'n Dienaar van die Woord in spesiale diens is beroep om evangelisasiewerk in die middestad van Johannesburg te doen. Die aanvanklike werk wat deur hierdie dienaar van die Woord gedoen word is dieselfde as die van 'n evangelis. Bykans op gelyke vlak is die werk wat opgedra was aan 'n persoon wat die lidmate van die Kerk in Angola moes bearbeid. Hy het nie die opleiding gehad wat die dienaars van die Woord ontvang het nie, maar die Kerk het aan hom bepaalde opdragte gegee wat noodsaaklik geag is vanweë toestande in Angola.

Die evangeliste se werksaamhede in die gemeente sal nou

19) Evangelism. International Missionary Council Meeting at Tambaram, Madras, 1938, Vol. III, Oxford University Press, London 1939, bl. 424. 
verband moet kan hou met die van die dienaars van die Woord. As in aanmerking geneem word dat hulle opgelei is deur die apostels kan die evangeliste vandag opgelei word in elke gemeente onder leiding van die dienaar van die Woord. Nie dat die dienaars van die Woord daarmee op gelyke voet met die Apostels geplaas moet word nie, omdat lg. groep op 'n besondere wyse ontvangers van die Openbaring was, maar omdat die dienaar van die Woord 'n deeglike opleiding ontvang het. Die beperking van die werkgebied van die Evangelis, ook t.o.v. sakramentsbediening moet dan gesien word in die lig van hul beperkte toerusting vir hulle dienswerk. Natuurlik spreek dit vanself dat die Kerk die besondere vereistes vir hul opleiding moet opstel. Vakansiekursusse en dergelike geleenthede kan daartoe dien dat die Evangelis behoorlik opgelei word en die kursusse kan daartoe dien om in 'n groot mate die opleiding te standardiseer. ${ }^{21}$ )

Hierdie evangeliste kom uit 'n bepaalde gemeente. In diẻ bepaalde gemeente kan hulle diens lewer. Die voordele van so 'n stelsel is legio. As lidmate van 'n bepaalde gemeente is hulle op hoogte met die plaaslike omstandighede. Hulle tree op in 'n sfeer aan hulle goed bekend en daarom sal hulle beter in staat wees om die nodige leiding te gee.

Die evangelis moet voortgaan met die werk waarvoor hy opgelei is. Dit skep geleentheid vir die evangelis om die afvalliges en vervreemdes saam met wie hy daagliks werk te konfronteer met die Woord.

Hier kan net ook sydelings daarna verwys word dat die vrou in die gemeente in die verband uiters waardevolle diens kan lewer. Hier kan verwys word na die werksaamhede van Priscilla (vgl. Hand. 18:26) Euodia en Sintiche (Filip. 4:23), Maria, Trifena en Trifosa (Rom. 16:6, 12).

\section{Slotopmerking :}

Daar bestaan by my geen illusies oor die talie vrae wat nog gestel kan word nie, en wat meer is oor die talle probleme en teenkanting wat ondervind sal word nie. Die nood van die Kerk maak dit egter gebiedend noodsaaklik dat oor die probleem van buitekerklikheid voortdurend besin sal word en 'n moontlike oplossing gevind moet word.

In gehoorsaamheid aan die Heer van die Kerk sal aan die

2n) Daar kan in die Kerk baie meer van dergelike kursusse gebruik gemaak word. Kerkraadslede, Sondagskoolonderwysers ens., kan alleenlik baat by iets van dergelike aard. 
afgedwaaldes en vorlorenes aandag gegee moet word. As daar dan nou na weë en middele gevra word moet dit Skriftuurlik verantwoordbaar wees, soos dit die geval is met die Evangelisteamp. 